\title{
Characterization of Nomuraea rileyi strains using polymorphic DNA, virulence and enzyme activity
}

\author{
Lúcia Rosane Bertholdo Vargas*, Marcelo Rossato, Rute Terezinha da Silva Ribeiro and \\ Neiva Monteiro de Barros \\ Universidade de Caxias do Sul; Instituto de Biotecnologia e Departamento de Ciências Biológicas; C. P. 1352; \\ 95001-970; n.barros@terra.com.br; Caxiasdo Sul-RS - Brazil
}

\begin{abstract}
The characterization of entomopathogenic microorganisms is important for the selection of more effective strains for use in integrated pest-control programs. Five Nomuraea rileyi strains (SA86101, GU87401, SR86151, CG128 and VA9101) were characterized using random amplified polymorphic DNA (RAPD) analysis, virulence studies and assessment of chitinolytic and proteolytic activity. RAPD analysis divided the strains into two groups with a similarity coefficient of 0,76\%, group 1 consisting of strains SA86101, GU87401 and SR86151 and group 2 of strains CG128 and VA9101. The $L_{50}$ varied from $165 \mathrm{~h}$ with strain VA9101 to $246 \mathrm{~h}$ with strain GU87401. Chitinolytic and proteolytic activity of the fungi after $144 \mathrm{~h}$ growth in minimal medium were tested using colloidal chitin as substrate. All strains exhibited enzyme activity, with strain VA9101 having the highest chitinase activity $\left(0,0040 \mathrm{\mu mol} / \mathrm{mL} / \mathrm{min}\right.$ the $\left.40^{\circ} \mathrm{C}\right)$ and strain $S A 86101$ the highest proteolytic activity. No relationship was found between RAPD analysis, virulence and chitinase or protease activity.
\end{abstract}

Key words: Nomuraea rileyi, Anticarsia gemmatalis, chitinase, protease, RAPD, virulence

\section{INTRODUCTION}

The large scale cultivation of soya (Glycine max) has resulted in the formation of agro-ecosystems which are very homogenous but unstable. The planting of this crop has brought with it associated problems such as the indiscriminate and excessive use of agrochemicals, which can generate adverse environmental effects by the contamination of soil, water and the food chain leading to possible human health problems. It is because of this that more research is being directed towards the development of biological control methods which are thought to be less damaging to the environment.
Since the insects which attack soya, especially the soya caterpillar (Anticarsia gemmatalis), are susceptible to a wide variety of natural enemies the inadequate or inappropriate use of agrochemicals can facilitate the occurrence of plagues of these insect by inhibiting the establishment of their natural enemies.

In Brazil, the entomopathogenic fungi Nomuraea rileyi is one of the principal agents used for the epizootic control of the soya caterpillar, thus helping to reduce the use of agrochemicals.

Spore germination is the first step in the chain of events leading to insect penetration by pathogenic fungi, but many other little-known factors are also involved in insect pathogenicity. Two such factors

* Author for correspondence 
are enzyme production and virulence, which have as yet been little studied in $N$. rileyi. In the work described in this paper we have characterized five $N$. rileyi strains using random amplified polymorphic DNA (RAPD) analysis and tried to establish their virulence and to relate this to the level of the activity of the proteolytic and chitinolytic enzymes produced by these strains.

\section{MATERIALS AND METHODS}

Five strains of the $N$. rileyi fungus were used, invigorated by bioassays, growing through 15 days for evaluation by RAPD, virulence, chitinases and proteases production.

Table 1 shows the geographic origin of the five $N$. rileyi strains used and the insect species from which they were isolated (Host).

The $N$. rileyi strains were inoculated, separately, into $100 \mathrm{~mL}^{-1}$ of MS medium (Mandels and Reese, 1960) supplemented with $1 \mathrm{mg} / \mathrm{mL}^{-1}$ ampicillin contained in $250 \mathrm{~mL}^{-1}$ flasks and cultivated for 10 days at $27^{\circ} \mathrm{C}$ in an orbital incubator at $150 \mathrm{rpm}$, after which the mycelia were filtered (Whatman $\mathrm{N}^{\circ} 1$ ), washed with sterile distilled water and resuspended in $90 \mathrm{~mL}^{-1}$ of MS medium (without either glucose or ampicillin) to produce a mycelial/conidial suspension.

For RAPD analysis the fungal DNA was extracted by maceration of $N$. rileyi conidia from the stocked strains in liquid nitrogen according to the method of Dellaporta et al. (1983). DNA profiles were produced by electrophoresis in $1.5 \%$ agarose gel, using $\lambda$ /HindIII and Eco RI as molecular markers, and the gels visualized with ethidium bromide under UV. The gels were photographed and analyzed, and a datasheet was prepared. The presence of a band was codified with " 1 " whereas its absence was indicated by " 0 ".

For the assessment of the virulence of each of the $N$. rileyi strains, 50 Anticarsia gemmatalis third instar larvae were placed in Petri plates lined with filter paper which had been impregnated with $2 \mathrm{~mL}^{-1}$ of a suspension containing $2 \times 10^{9}$ conidia $/ \mathrm{mL}^{-1}$. Three replicates were made for each treatment and controls were prepared using the same methodology, except that the filter papers were moistened with sterile solution Tween 80$0.1 \%$ in place of conidial suspension. The plates were placed in an incubator (FANEM, Brazil) for $24 \mathrm{~h}$ at $26^{\circ} \mathrm{C}, 65 \%$ relative humidity under a $12 \mathrm{~h}$ photoperiod, after which the larvae were transferred to flasks (5 larvae/flask) containing an artificial diet (Greene et al. 1976) and returned to the incubator. Insect mortality was evaluated daily until the insects pupated.

Table 1 - Geographical origin and host insect of the Nomuraea rileyi strains used in the experiments.

\begin{tabular}{ccc}
\hline Strain & Geographic origin & Host Insect $^{1}$ \\
CG128 & Sete Lagoas & Spodoptera frugiperda \\
GU87401 & Guaíba & A. gemmatalis \\
VA9101 & Vacaria & A. gemmatalis \\
SA86101 & Sarandi & A. gemmatalis \\
SR86151 & Santa Rosa & Rachiplusia ni \\
\hline
\end{tabular}

${ }^{1}$ Strain CG128 was from the Brazilian state of Minas Gerais, all other strains were from the Brazilian state of Rio Grande do Sul.

For enzyme induction, each fungal strain was cultivated as above except that $10 \mathrm{~mL}^{-1}$ of MR media, containing $1 \mathrm{~g}$ of colloidal chitin (Amagase et al. 1972), was added to each flask. The flasks were incubated at $27^{\circ} \mathrm{C}, 150 \mathrm{rpm}$ for 6 days. After incubation the culture media was filtered (Whatman $\mathrm{N}^{\circ} 1$ ) and the filtrate stored at $4^{\circ} \mathrm{C}$ until analysis of chitinase and protease activity. Chitinase activity was assessed using colloidal chitin as substrate (Pinto et al., 1997) and a modified colorimetric method for the estimation of $\mathrm{N}$-acetylamino sugars using N-acetyl-Dglucosamine as a standard (Reissig et al. 1955). One enzyme unit was defined as the quantity of enzyme that catalyses the liberation of $1 \mu \mathrm{mol}$ of $\mathrm{N}$-acetylglucosamine/minute $/ \mathrm{mL}^{-1}$ at $40^{\circ} \mathrm{C}$. Proteolytic activity was determined using the method of Sarath et al. (1989), one protease unit 
being defined as the quantity of enzyme required to produce a $440 \mathrm{~nm}$ of 1 unit $/ 30$ minutes in a $1 \mathrm{~cm}$ path-length cuvette under the conditions of the assay.

\section{RESULTS AND DISCUSSION}

In microbiological control programs the analysis of variability between strains is an important factor which follows on from the characterization of isolates collected from the ecological system into which a pathogen was introduced. This is because a knowledge of the variability between strains facilitates posterior ecological studies of introduced isolates, the precise identification of which is a prerequisite for patent registration and the production of a commercial product of improved microorganisms.

Ten of fifteen primers tested were chosen for characterization of strains. Previously, Rossato (1996) examined primers to identify polymorphism in $N$. rileyi, and obtained the best results with OPW-04, OPY-08, and OPX-17.

Figure 1 shows the profiles of the amplified segments of the five $N$. rileyi strains (numbered 26) along with a molecular marker (numbered 1).

\section{$\begin{array}{llllll}1 & 2 & 3 & 4 & 5 & 6\end{array}$}

Figure 1 - Profiles of amplified RAPD segments generated by the OPW-13 primer. $1=\lambda / H$ indIII and Eco $R I$ molecular markers, $2-5=N$. rileyi strains $(2=$ GU87401, 3= SR86151, 4= SA86101, $5=$ CG128 and $6=$ VA9101).

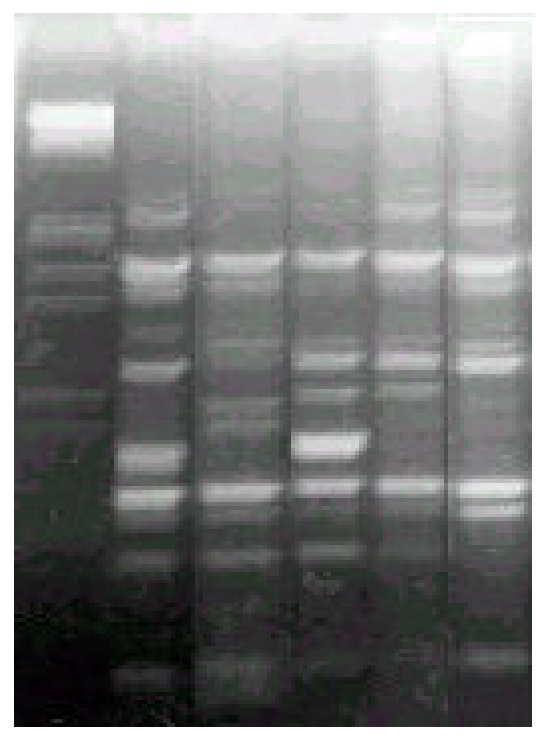

Figure 2 shows the dendrogram based on Jaccard similarity $\left(\mathrm{S}_{\mathrm{J}}\right)$ coefficients obtained from the RAPD data subjected to unweighted pair group method with averages (UPGMA) analysis, the $\mathrm{S}_{\mathrm{J}}$ values ranging from $0.76-0.83$.

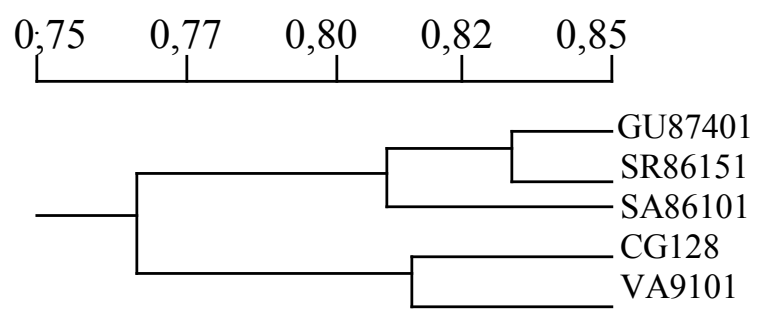

Figure 2 - Dendrogram of the relationship between five $N$. rileyi strains as based on RAPD analysis.

Two distinct groups can be seen in Figure 2, group I consisting of strains SA86101, GU87401 and SR86151 and group II of strains VA9101 and CG128, the similarity between the strains as a whole being $>0.8$.

These results demonstrate the high degree of homology between the different $N$. rileyi strains studied, irrespective of their

geographic origin and the host from which they were isolated. These are comparable to the results observed by Rossato (1996) working with other $N$. rileyi strains. Similar results have also been encountered for different strains of other filamentous fungi by Bidochka et al. (1994) working with Metarhizium flavoviride and Metarhizium anisopliae and Cravanzola et al. (1997) working with Beauveria brongniartii. These authors found no relationship between genetic distance and geographic origin or host. However, Leal et al. (1994), working with $M$. anisopliae, were able to differentiate not only between isolates from the same country but also between isolates from different geographic sites in the same country.

Fungaro et al. (1996), showed that isolates of $M$. anisopliae var. anisopliae are extremely diverse (47\% similarity) but those isolated from Deois flavopicta present only a moderate degree of variation $(82 \%$ similarity) when compared with the wide diversity ( $31 \%$ similarity) found in the group isolated from soil. These results suggest that 
M. anisopliae var anisopliae has developed host specificity.

In a genetic study of Paecilomyces fumosoroseus isolates, Cantone and Vandenberg (1998) used 9 primers to obtain 365 polymorphic bands which were used to construct a similarity matrix and a dendrogram in which the isolates formed 3 large groups with a similarity of $0.5-0.99$. Due to the high level of polymorphism within the group, these authors also could not group the isolates based on geographic origin or host.

Table 2 gives the results of the virulence experiments and it can be seen that the confidence intervals of all the strains overlap, indicating no significant difference between the strains.

Table 2 - Mean lethal time $\left(\mathrm{TL}_{50}\right)$ for Anticarsia gemmatalis treated with a suspension containing $2 \times 10^{9}$ Nomuraea rileyi conidia/ $\mathrm{mL}^{-1}$.

\begin{tabular}{cccc}
\hline Strain & $\begin{array}{c}\text { Geographic origin }^{\mathbf{a}} \\
\text { (host in italics) }^{\text {Vacaria }}\end{array}$ & TL $_{\mathbf{5 0}}$ (days) $^{\mathbf{b}}$ & Confidence intervals \\
VA9101 & A. gemmatalis & 165 & $\% 146.34$ \\
& Sete Lagoas & & $\% 187.38$ \\
CG128 & S. frugiperda & 200 & $\% 177.73$ \\
& Sarandi & 200 & $\% 225.14$ \\
SA86101 & A. gemmatalis & & $\% 179.71$ \\
& Santa Rosa & 243 & $\% 224.55$ \\
SR86151 & R. $n$ i & & $\% 271.12$ \\
& Guaíba & 246 & $\% 227.68$ \\
GU87401 & A. gemmatalis & & $\% 266.43$ \\
& & & \\
\hline
\end{tabular}

${ }^{a}$ Strain CG128 was from the Brazilian state of Minas Gerais, all other strains were from the Brazilian state of Rio Grande do Sul.

${ }^{\mathrm{b}}$ Rounded to the nearest day.

Tabela 3 - Chitinase activity of Nomuraea rileyi strains.

\begin{tabular}{lccc}
\multicolumn{1}{c}{ Strain } & $\begin{array}{c}\text { Chitinase production }^{\mathbf{a}} \\
(\boldsymbol{\mu \text { mol } )}\end{array}$ & Variance & $\begin{array}{c}\text { Mean Chitinase Activity } \\
\left(\boldsymbol{\mu \mathbf { m o l }} / \mathbf{m i n} / \mathbf{m L}^{-1}\right)\end{array}$ \\
VA9101 & $0.060 \pm 0.008$ & 0.00007 & $0.0040 \mathrm{a}$ \\
GU87401 & $0.032 \pm 0.005$ & 0.00003 & $0.0021 \mathrm{~b}$ \\
CG128 & $0.123 \pm 0.006$ & 0.00003 & $0.0020 \mathrm{~b}$ \\
SR86151 & $0.013 \pm 0.003$ & 0.00001 & $0.0009 \mathrm{c}$ \\
SA86101 & $0.009 \pm 0.003$ & 0.00001 & $0.0006 \mathrm{c}$ \\
\hline
\end{tabular}

${ }^{\mathrm{a}}$ Mean of 3 flasks each containing $100 \mathrm{~mL}-1$ of inoculated culture medium.

${ }^{\mathrm{b}}$ One enzyme unit is the quantity of enzyme that catalyses the liberation of $1 \mu \mathrm{mol}$ of $\mathrm{N}$-acetylglucosamine $/ \mathrm{minute} / \mathrm{mL}$ at $40^{\circ} \mathrm{C}$.

${ }^{\mathrm{c}}$ Means followed by the same letter do not differ statistically (Duncans test, $\mathrm{P}<0.05$ ).

Table 3 present the results of the chitinase experiments and it can be seen that there are significant differences (Duncans test, $\mathrm{p}<0.05$ ) between some of the strains, with strain VA9101 having the highest chitinase activity.

These results show no statistically significant relationship between chitinase activity and virulence. This was because although strain VA9101 gave both the shortest $\mathrm{TL}_{50}$ value and the highest chitinase activity, the strain which gave the second highest chitinase activity, strain GU87401, gave the longest $\mathrm{TL}_{50}$ value.

It should be noted that the while there were significant differences (Duncan's test, $\mathrm{P}<0.5$ ) between chitinase values there were no significant differences between $\mathrm{TL}_{50}$ values.

The culture media used in the enzyme production experiments contained $1 \%$ colloidal chitin, which means that the experimental conditions differed from those found in the field.

It is possible that the results produced were due to the experimental conditions, and that in nature there is a relationship between chitinase production and virulence.

El-Sayed et al. (1989) have suggested that the combined action of chitinases and proteases is important in the penetration of the larval integument by $N$. rileyi. The high level of 
protease activity during the infection process implies an important function for this class of enzymes, this being due to the fact that protein is the major structural component of insect cuticles (St. Leger et al., 1987; Goettel et al., 1989). Table 4 show the results of the protease production experiments. It can be seen that strain SA86101 produced the highest protease activity while strain CG128 produced the lowest.

Although strain SA86101 produced the highest protease activity, its $\mathrm{TL}_{50}$ value was 201 days.
Strain VA9101, which had the lowest $\mathrm{LT}_{50}$ value (165 days), was the strain with the second lowest protease activity, although it had the highest chitinase activity.

Although Barros et al. (2000) have suggested a correlation between enzyme activity and virulence, in our experiments it was not possible to verify this type of relationship.

Table 4 - Protease activity of Nomuraea rileyi strains

\begin{tabular}{|c|c|c|}
\hline Strain & Protease Activity $^{\text {ab }}$ & Variance \\
\hline SA 86101 & $0.055 \pm 0.003 \mathrm{~d}$ & 0.000009 \\
\hline GU 87401 & $0.045 \pm 0.003 c$ & 0.000400 \\
\hline SR 86151 & $0.032 \pm 0.004 b$ & 0.000199 \\
\hline VA 9101 & $0.026 \pm 0.019 b$ & 0.000200 \\
\hline CG 128 & $0.007 \pm 0.003 \mathrm{a}$ & 0.000010 \\
\hline
\end{tabular}

Since enzyme activity is highest when conidia attach to the larval cuticle, it seems that there are other factors involved in the penetration process. Possibly chemical recognition between the fungal conidia and the insect cuticle or the involvement of other secondary metabolites such as fungal toxins (Onofre et al., 1999). It should be noted that the enzymes were assayed separately, and that virulence may be the result of a set of enzymes acting together.

St. Leger et al. (1988) worked with virulent mutants of $M$. anisopliae, they found that virulence correlated with high protease (chymoelastase) activity, which caused lysis of proteins in the insect (Manduca sexta) tegument, facilitating fungal penetration.

The mechanisms which govern the pathogenicity of fungi towards insects has been much studied. For example, St. Leger et al. (1987) have demonstrated that $M$. anisopliae and B. bassiana proteases are virulence factors in the attack of insects by these two fungi. In studies with $M$. anisopliae, these authors cloned and sequenced the cuticle-degrading-protease (Pr1) gene (St. Leger et al., 1992), making it possible to select the presence or absence and the copy number of this protease.
The naturally occurring entomopathogenic fungus $N$. rileyi has great potential for use as a bioinsecticide, but there are few studies in relation to the use of this organism for biocontrol. The results published in this paper open new perspectives on the mechanism of action of $N$. rileyi and provide a basis for the new studies which are needed to establish the relationship between the diverse biotic and abiotic factors which govern the complex mechanisms of action of this fungi.

\section{ACKNOWLEDMENTS}

The present work is a part of an M.Sc. Thesis presented at the Biotechnology Institute, University of Caxias do Sul (UCS), Brazil. The authors acknowledge the finantial support from Universidade de Caxias do Sul and Fundação de Amparo a Pesquisa do Estado do Rio Grande do Sul.

\section{RESUMO}

Caracterizaram-se cinco linhagens de $N$. rileyi por análise de RAPD, avaliação da virulência e 
atividade enzimática (quitinolítica e proteolítica). Pela técnica de RAPD foi possível distinguir, entre as cinco linhagens avaliadas, dois grupos com similaridade 0,76: grupo I (linhagens SA86101, GU87401, SR86151) e grupo II (linhagens VA9101 e CG128). O TL $\mathrm{TL}_{50}$ variou de 165 horas com a utilização da linhagem VA9101 a 246 horas com GU87401. Todas as linhagens apresentaram atividade quitinolítica e proteolítica, destacando-se quanto à produção de quitinases a linhagem VA9101 (com $0,0040 \mu \mathrm{mol} / \mathrm{mL} / \mathrm{min}$ a $\left.40^{\circ} \mathrm{C}\right)$ e em relação à protease, a linhagem SA86101. Não foi possível evidenciar relações entre virulência, análise genética e atividade enzimática.

\section{REFERENCES}

Amagase, S.; Mote, M. and Nakayama, S. (1972), Enzymatic digestion of insect by Nepenthes secretion an Drossera peltata. Extract: proteolytic and chitinolytic activities. Biochem., 72, 765-767.

Barros, N. M; Rossato, M. and Onofre, S. B. (2000), Nomuraea rileyi como agente de controle microbiano da lagarta-da-soja. In: I. S. Melo, J. L. Azevedo. Controle Biológico II. Embrapa Meio Ambiente, Jaguariúna. 308 pp.

Bidochka, M. J.; Mcdonald, M. A.; St. Leger, R. J. and Roberts, D.W. (1994), Differentiation of species and strains of entomopathogenic fungi by random amplification by polymorphic DNA. Curr. Gen., 25, 107-113.

Cantone, F. A. and Vandenberg, J. D. (1998), Intraspecific diversity in Paecilomyces fumosoroseus. Mycol. Res.,102, 209-215.

Cravanzola, F.; Piatti, P.; Bridge, P. D. and Ozino, O. I. (1997), Detection of genetic polymorphism by RAPD-PCR In strains of the entomopathogenic fungus Beauveria brongniartii isolated from the European cockchafer (Melolontha spp.), Lett. Appl. Microbiol., 25, 289-294.

Dellaporta, S. L.; Wood, J. and Hicks, J. B. (1983), A plant DNA minipreparation: version II, plant mol. rep. In: Weising, K.; Nybom, H.; Wolff, K. and Meyer, W. DNA fingerprinting in plants and Fungi, 4, 19-21

El-Sayed, G. N.; Coudron, T. A. and Ignoffo, C. M. (1989), Chitinolytic activity and virulence associated with native and mutant isolates of an entomopathogenic fungus Nomuraea rileyi. $J$. Invertebr. Pathol., 54, 394-403.

Fungaro, M. H. P.; Vieira, M. L. C.; Pizzirani-Kleiner, A. A. and Azevedo, J. L. (1996), Diversity among soil and insect isolates of Metarhizium anisopliae var. anisopliae detected by RAPD. Letters in Applied Microbiology, 22, 389-392.

Goettel, M. S.; St. Leger, R. J.; Rizzo, N. W.; Staples, R. C. and Roberts, D. W. (1989), Ultrastructural localization of a cuticle-degrading protease produced by the entomopathogenic fungus Metarhizium anisopliae during penetration of host (Manduca sexta) cuticle. J. Gen. Microbiol., 135, 2233-2239.

Greene, G. L.; Leppla, N. C. and Dickerson, W. A. (1976), Velverbean caterpillar: a rearing procedure and artificial medium. J. Econ. Entomol., 69, 487488.

Leal, S. C. M.; Bertioli, D. J.; Butt, T. M. and Peberdy, J. F. (1994), Characterization of isolates of the entomopathogenic fungus Metarhizium anisopliae by RAPD-PCR. Mycol. Res., 98, 1077-1081.

Mandels, M. and Reese, E. T. (1960), Induction of cellulases in fungi by cellobiose. J. Bacteriol., 79, 816-826

Onofre, S. B.; Riveros, R.; Costa, S. O. P. and Barros, N. M. (1999), Avaliação da atividade antimicrobiana de metabólitos produzidos pelo fungo Nomuraea rileyi (Farlow) Samson. Arq. Cienc. Saúde Unipar, 3, 29-33.

Pinto, A. S.; Barreto, C. C.; Schrank, A.; Ulhoa, C. J. and Vainstein, M. H. (1997), Purification and characterization of an extracellular chitinase from the entomopathogen Metarhizium anisopliae. Can. J. Microbiol., 43, 322-327.

Reissig, J. L.; Strominger, J. L. and Leiloir, L. F. (1955), A modified colorimetric method for the estimation of N-Acetylamino sugars. J. Biol. Chem., 217, 957-967.

Rossato, M. (1996), Caracterização molecular de linhagens do fungo Nomuraea rileyi (Farlow) Samson por análise de RAPD (Dissertação de Mestrado). Caxias do Sul : IB/UCS. 83 pp.

Sarath, G.; De La Motte, R. and Wagner, F. W. (1989), Protease assay methods. In: Beynon, R. J. and Bond, I. S. Proteolitic assay: a pratical aprouch. Oxford : I.R.C. Press

St. Leger, R. J.; Charnley, A. K. and Cooper, R. M. (1987), Characterization of cuticle-degrading proteases produced by the entomopathogen Metarhizium anisopliae. Arch. Biochem. Biophys, 253, 221-232.

St. Leger, R. J.; Durrands, P. K.; Charnley, A. K. and Cooper, R. M. (1988), Role of extracellular chymoelastase In The virulence of Metarhizium anisopliae for Manduca sexta. J. Invertebr. Pathol., 52, 285-293.

St. Leger, R. J.; Frank, D. C.; Roberts, D. W. and Staples, R. C. (1992), Molecular cloning and regulatory analysis of the cuticle-degrading-protease structural gene from the entomopathogenic fungus Metarhizium anisopliae. Eur. J. Biochem., 204, 991-1001. 
Received: April 25, 2001; Revised: November 27, 2001; 